\title{
'The Reality Effect': the Figure Seen from Behind in Carracci's Art*
}

\begin{abstract}
This article focuses on Carracci's frequent use of the figure seen from behind in their graphic and pictorial oeuvre (i.e., in the frescoes in Palazzo Fava, in the Cloister of San Michele in Bosco by Ludovico, in the series of the Diverse Figure by Annibale, and the engraving Ogni cosa vince l'oro by Agostino). It claims that the figure seen from behind plays a rhetorical function instrumental to the Carracci's search for a new form of naturalism in painting. In particular it creates a 'reality effect' that enhances the naturalistic rendering of the pictorial composition.
\end{abstract}

According to Carlo Cesare Malvasia's Felsina Pittrice, when Annibale Carracci was painting the Venus with a Satyr and Cupids, he asked his cousin Ludovico to be his model for depicting the back of the Venus: "The Carracci made a practice of posing as models for one another; Agostino prided himself in being able to adopt the exact poses and attitudes desired by Ludovico, for he believed that anyone who did the poses of the professional models were artificial and lifeless. Nor did Ludovico, who was rather plump and fleshy, deem it beneath him to strip to the waist and have his back copied by Annibale in the attitude needed for the Venus in the picture that the Bolognetti later sold to their Serene Highnesses of Florence and that can be found today among the other famous pictures in the royal museum". ${ }^{2}$ Apart from referencing a painting with a figure seen from behind, this quote is extraordinarily appropriate in emphasising Annibale's need to depict the truth, or - using his own words - the 'vi-

\footnotetext{
* I would like to thank Mattia Biffis for the opportunity to take part in the Roman workshop 'The Art of Truth', and all the participants for the valuable debate. I would like to share my gratitude to Marco Ruffini, Serena Quagliaroli, Valentina Balzarotti, Vittoria Brunetti, Elania Pieragostini, Caroline Swinton and the staff of the Biblioteca Nazionale di Storia dell'arte of Rome, particularly to Mauro and Silvia.

${ }^{1}$ See catalogue entry by Brogi in Benati and Riccomini 2006, 198-199.

2 Summerscale 2000, 120 ("Usavano farsi modello fra di loro; godeva Agostino di accomodarsi nella attitudini bramate da Lodovico, essendo di questa opinione, che chi non le intendeva, non le sapesse ben rappresentare e perciò quelle de' modelli fossero posticce ed insipide; né sdegnò Lodovico, ch'era cicciosotto e polputo, spogliatosi fino alla cintura, lasciar copiar la sua schiena ad Annibale nella Venere volta in quell'attitudine, che poi da' Signori Bolognetti fu venduta alle Altezze Serenissime di Firenze, ed oggi trovasi fra l'altre pitture famose del Real Museo". Malvasia 1678, I, 378); Summerscale 2000, 120 (n. 80).
} 
vo' ${ }^{3}$ in order to give Venus a real back, 'viva', the painter is willing to use as a model that of a man, his 'plump and fleshy' cousin, Ludovico. Using a number of elements, such as the quoted anecdote, among early sources as well as the most recent literature, this article explores the possible link between the decision to depict a figure from behind and the wellknown pursuit of painting based on the imitation of nature and reality by the three artists. The choice of focusing on this topic through the art of the Carracci is based on their devotion to the 'truth', practised and taught throughout their lives as the driving force of their artistic reformation. ${ }^{4}$

The first work is the frieze with stories of Jason, frescoed by the three cousins from 1584 in one of the rooms of the palace of the Fava family in Bologna. ${ }^{5}$ In the Felsina Pittrice, Malvasia provides a precise description of the frieze, supplying iconographic and stylistic details on each of the frescoes. In explaining the seventh scene, depicting The Argonauts in the Lybian Desert (FIG. 2), Malvasia focuses on the figure of Hercules in the foreground, who is about to strike the lion: "Ercole volto pur qui in ischiena, per mostrarci quella fortezza, che da gli omeri rilevati s'argomenta, al leon già ferito, mena colpo di mazza, e col piè atterra". 6 Malvasia wrote 'also here' as the hero, who can be recognised by his club, also turned his back to the viewer in the two previous scenes, The Construction of the Argo and The Embarkation of the Argonauts (FIG. 1). In describing the latter, Malvasia had already explained Hercules' pose: 'più grande ancora con l'altre figure ci fanno apparire quell'Ercole, che volto in ischiena con la man sul fianco, sta rimirando il salir de compagni". 7

Despite the evident stylistic differences among these three depictions due both to the different painters who worked on the same scene and the later retouchings, it is interesting that Ludovico, Agostino and Annibale decide to depict Hercules from behind on more than one occasion. ${ }^{8}$ In the first two episodes, the figure is at rest, as a beholder of the main action: in the first episode, he is depicted with a solid stance, his feet wide apart, while in the second episode he appears 'sfiancheggiante'. ${ }^{9}$ In the seventh scene, on the other hand, the imposing figure of Hercules twists his body to funnel the strength needed to kill the lion. In the critical interpretation that Malvasia supplied at the end of the description of the frieze, when analysing the last-mentioned fresco, he highlights Annibale's skills in using different poses for the

\footnotetext{
3 The quote comes from Annibale's Postille to Vasari's Vite (see Benati and Riccomini 2006, 460).

${ }^{4}$ See Benati and Riccomini 2006, 18-37; Keazor 2007; Benati 2016.

${ }^{5}$ On the Jason Frieze see: Emiliani 1984; Robertson 1993, 271-305; Campbell 2002, 210-230; Perini Folesani 2006, 189211; Robertson 2008, 77-82.

${ }^{6}$ Malvasia 1678, I, 370 ("Here Hercules is shown with his back to us, so that his strength is persuasively demonstrated to us by his bulging shoulders, and he delivers a blow with his club to a wounded lion while forcing it to the ground with a thrust of his leg". Summerscale 2000, 105). I prefer to use the Italian version in the main text to stress the expression reported in italics, 'pur qui', that has not been translated in Summerscale 2000.

${ }^{7}$ Malvasia 1678, I, 370 (“...including the Hercules who stands with his back to us and his hand on his hip, and gazes at the embarkation of his companion". Summerscale 2000, 105).

${ }^{8}$ On the motif of Hercules seen from behind see Rubin 2018, 126-143. For the attribution of individual scenes and figures see Emiliani 1984, 104-111.

${ }^{9}$ Malvasia used this word in his book Le pitture di Bologna, to describe the figure of Saint George in the altarpiece painted by Ludovico Carracci for the church of Santi Gregorio e Siro in Bologna (Malvasia 1686, 114; on the altarpiece see Brogi 2001, 183-184). As Giovanna Perini Folesani noted, this term can be interpretated as an original translation of the typical 'hanchement' of the Mannerist figure (see Perini Folesani 1980, 240). Summerscale translates "sfiancheggia" to "exaggerated swaying pose" (Summerscale 2000, 211).
} 
different figures: "s'un di essi in faccia si vede, l'altro è posto di fianco, l'atro in ischiena vedesi". ${ }^{10}$ To reiterate the virtuosity of this choice, Malvasia quotes a passage from De Arte Graphica by "Orazio gallico pittore", that is Charles Dufresnoy, where the author advocates that in depicting a group of figures, they will be captured in different poses, including from behind. ${ }^{11}$ There are obviously many cases where a figure seen from behind is included solely on account of this pursuit of variety - obeying compositive rules such as the ones formulated by Dufresnoy. However, in the depiction of Hercules in the frescoes of Palazzo Fava, Malvasia himself provides suggestions for performing more in-depth research.

In the above-mentioned passages from the Felsina Pittrice dedicated to the description of the hero, Malvasia identifies a precise relationship between the figure's pose and his action. In The Embarkation of the Argonauts, Hercules "gazes at the embarkation of his companion": 12 in this scene the hero carries out the same action in the same pose as the viewers, presenting himself as a hypostasis of the viewers themselves. ${ }^{13}$ In commenting The Argonauts in the Lybian Desert, Malvasia writes that Hercules "is shown with his back to us, so that his strength is persuasively demonstrated to us by his bulging shoulders", therefore explaining his pose with the aim of expressing his physical effort in the most incisive way. ${ }^{14}$

Finally, the identification of a link between the pose and the action also emerges from Malvasia's description of the frescoes, now almost completely lost, that Ludovico Carracci designed for the Cloister of San Michele in Bosco at Bologna. ${ }^{15}$ This text, published posthumously in 1694, is a comment to the renowned sonnet that Agostino Carracci wrote in praise of Niccolò dell'Abate. ${ }^{16}$ Malvasia links the verse "Movements from the Venetians, and their shade" - "La mossa, coll'ombrar Veneziano" - to the work of Tintoretto, acknowledging that Robusti had done "il più valid'uso al certo, e efficace pratica" of the "Mossa, o sia moto, o movenza delle Figure", and highlighting how Ludovico, in the frescoes depicting stories of Saint Benedict, had also similarly given "qualche moto fuor del consueto alle Figure". ${ }^{17}$ This motion can be observed in the nudes of Saint Benedict Drives the Demon off the Immovable Stone (FIG. 3), in the scene of Saint Benedict exorcising a Demon, in the soldier of The Burning in Montecassino, in the The Crazy Woman, but especially in The Fire in the Kitchen (FIG. 4). In painting the latter, Ludovico "pienamente trasformatosi nel sopradetto Robusti, ansi in Tiziano con più giustezza imitante il Robusti, si dimostrass'egli grand'osservatore della Mos-

\footnotetext{
${ }^{10}$ Malvasia 1678, I, 373 (“...when one of them is seen in full face, the next one is placed sideways, and if one is seen from the side, another is seen from the back". Summerscale 2000, 109).

${ }^{11}$ Malvasia 1678, I, 372-373; Summerscale 2000, 109 (n. 59); see also Dufresnoy 2005 [1668], 186-187, $276-277$.

${ }^{12}$ Summerscale 2000, 105.

${ }^{13}$ The topic of the bystander seen from behind will be further investigated in the following pages of this essay.

${ }^{14}$ Summerscale 2000, 105. For this figure, some scholars have proposed to compare it with the executioner painted by Federico Barocci in the Martyrdom of Saint Vitale (Ravenna); see Ambrosini Massari 2009, 128, 136 (n. 56) with earlier bibliographical references.

${ }^{15}$ On the Cloister of San Michele in Bosco, see Emiliani 1993, LX-LXIII; Campanini in Emiliani 1993, 179-198; Campanini 1994; Summerscale 2000, 213 (n. 278).

${ }^{16}$ For the debate on the paternity of the sonnet see Perini Folesani 1990 (in particular pages 58-69); Pierguidi 2014, 6878. On the sonnet see also Unger 2019, 36-40. On the Malvasia's Il Claustro di S. Michele in Bosco di Bologna, see Dempsey 2013.

${ }^{17}$ Malvasia 1694, 13. For the English translation of the sonnet see Holt 1958, 73-74.
} 
sa Veneziana". ${ }^{18}$ Malvasia was so impressed by the artist's great skill in expressing the incitement of the lay brothers filling up buckets at the well to extinguish the fire, that he justified Carracci's liberty in showing their naked legs and arms, "per dimostrarci magistralmente in quelle agitazioni di membra, il vero, e sicuro effetto de' muscoli in quel violente moto alterati". 19

According to Malvasia, Ludovico rendered the movement of the figures in a way that perfectly corresponds to the teachings by Leonardo da Vinci in his Treatise on Painting, and namely in a passage in Chapter 233, where he analysed "Dell'apparecchio della forza dell'Huomo, che vuol generare gran percussion". ${ }^{20}$ Ludovico, "per render più vigoroso il lancio dell'Acqua di che pieno è il Secchio" of the lay brothers, makes them turn "impetuosamente le braccia, perché più vigorosamente elleno poi si stesano, e si allonghino alla vibrazione", as suggested by Leonardo. ${ }^{21}$ Malvasia's interest in Leonardo's treatise is also confirmed by another quote used to comment the fresco by Domenichino in the Oratory of Sant'Andrea al Cielo in Rome: "ne gl'infuriati Manigoldi, ma specialmente in quello, che in prima veduta a noi volto il tergo, e alzate le concordi braccia, a vibrare più pesante il colpo dell'impugnate verghe, slogando in dietro la gamba, fa vedere quanto coll'apparecchio anch'egli della sua forza sappiasi ben disporre a generare la sopra accennata dal Vinci, gran percussione; anzi a praticare quanto ei dimostra nella figura proposta al cap. CCXXXIV della forza composta dell'huomo, e prima delle braccia". ${ }^{22}$

Since in Leonardo's treatise there is no direct reference to the importance of depicting the body as seen from behind, it is not really surprising that Giovan Pietro Bellori quotes the same passage in his interpretation of Polyphemus hurling the rock at Acis, painted by Annibale in the Galleria Farnese, where the figure is facing the viewer. ${ }^{23}$ Both authors use Leonardo's quote to prove the artist's skill in rendering the movement exactly as it is in nature, but Malvasia always associates it with figures seen from behind. In fact, for this kind of action, as Leonardo himself writes, twisting is essential, and the back muscles are the ones better suited to convey the effort. From this perspective, the view from behind appears as the device that shows more 'truth' in the movement.

\footnotetext{
${ }^{18}$ Malvasia 1694, 13. Malvasia refers to the lost altarpiece painted by Titian, representing the Martyrdom of Saint Peter, originally located in San Zanipolo in Venice. He had already noted in the Felsina Pittrice that this work reveals how Titian studied Tintoretto's oeuvre and in particular how Tintoretto rendered the movement of the bodies. For a copy of the altarpiece by Annibale Carracci see Summerscale 2000, 99-100 (n. 41).

${ }^{19}$ Malvasia 1694, 13. Malvasia had already highlighted the "strepitose mosse" of the monks in the Felsina Pittrice, quoting the above-mentioned altarpiece by Titian (Malvasia 1678, I, 436; see also Summerscale 2000, 213).

${ }^{20}$ For Carracci's knowledge and reception of Leonardo's Treatise on Painting see Leonardo 1995, 65-66; Pedretti 1996, 65-66; Laurenza 2005, 343-346; Barone 2015, 457. The name "Vinci" is written on the spine of a book in one of the finalini that decorate the first editions of the Felsina Pittrice and the Claustro di San Michele in Bosco (e.g. see Malvasia 1694, 8). I am grateful to Giovanna Perini Folesani for this suggestion.

${ }^{21}$ Malvasia 1694, 14. Leonardo wrote: "A Man disposing himself to deal some violent Stroke, bends, and turns from the Mark at Which he aims, with a Motion, contrary to that wherewith he intends to strike; where, collecting all his Force, he lets it fly; and discharges it on the Body that he hits, with a compound Motion, form'd out of that of the Arm, and of the Weapon that he holds" (Leonardo 1721, 122-123).

${ }^{22}$ Malvasia 1694, 15. Malvasia makes a mistake on the chapter number. The chapter he quotes is the 233.

${ }^{23}$ Bellori 1672, 60 .
} 
Precision in the depiction of the anatomy was one of the greatest concerns of the Carracci, and one of the most reliable ways to achieve success in their "battle for the truth". ${ }^{24}$ This is also shown by the importance reserved to the anatomical studies in the curriculum of the artistic Academy they founded. As explained by Roberto Paolo Ciardi, it is appropriate to distinguish their different degrees of interest in the practice of human dissection: Agostino considered it essential, Annibale was not sure of the need to "cacciarsi dentro" the bodies ${ }^{25}-$ a practice, he believed, to be more appropriate for doctors - while Ludovico merged the two approaches, that of destruction typical of anatomical analysis, and that of creation pertaining to the artistic pursuit. ${ }^{26}$

This union is visible in some of Ludovico's works where, as in the above-mentioned frescoes in the Cloister of San Michele, the pose from behind is intrinsically related to the action performed by the figure. Consider the two paintings that Ludovico depicted at the beginning of the $17^{\text {th }}$ century: the altarpiece for the Corpus Domini Sanctuary in Bologna (FIG. 5$)^{27}$ and that for the Cathedral of Piacenza (FIG. 6$)^{28}$ - now in the Galleria Nazionale di Parma - both depicting The Apostles at the Virgin's Tomb. Comparing these two paintings to others by Ludovico of the same subject, one notices a shift of the artist's focus from the Assumption of the Virgin to the earthly discovery of the empty tomb. ${ }^{29}$ In the Bolognese altarpiece the holy scene is retained in the upper part of the composition, although it is the mystical union between Mary and Christ rather than the Assumption. Gail Feigenbaum effectively pointed out that the celestial event acts as a 'gloss' which assures the intelligibility of the scene. ${ }^{30}$ This complies with the rules established by Paleotti and also helps understand the real subject of the painting: the all-human apprehension of the apostles in discovering the empty tomb. ${ }^{31}$ "Ludovico makes it clear that physical and spiritual discoveries are not simultaneous. He presents what these men must have experienced at this moment, stunned by the empty tomb, stricken with anguish and confusion. The apostles peer into the tomb and touch the shroud with their hands, but the perceptions of the senses are not adequate. Nor is reason". ${ }^{32}$

In the altarpiece for the Corpus Domini, the artist clearly emphasises the inadequacy both physical and psychological - of the apostles' human nature. If the confused and anguished facial expressions show their difficulty in understanding the event, their frenzied gestures and tense muscles suggest the tangible reality of the moment. In her essay on the iconography of the Assumption, Else Staedel asserts that this is the first time that the physical

\footnotetext{
${ }^{24}$ Emiliani 1993, XXXV.

${ }^{25}$ The quote comes from Annibale's Postille to Vasari's Vite (see Benati and Riccomini 2006, 461).

${ }^{26}$ Ciardi 1993; see also Robertson 2008, 74-75; Pigozzi 2012; Pigozzi 2013.

${ }^{27}$ See catalogue entry by Feigenbaum in Emiliani 1993, 120-122; Brogi 2001, 185-186.

${ }^{28}$ Emiliani 1993, LXIII-LXVII; Brogi 2001, 209.

${ }^{29}$ Other altarpieces depicting the Assumption of the Virgin are in the North Carolina Museum of Art in Raleigh (see Pinnel 1958; Feigenbaum in Emiliani 1993, 37-39; Brogi 2001, 124-126) and in the Galleria Estense of Modena (see Street 1970; Feigenbaum in Emiliani 1993, 146-147; Brogi 2001, 200-201).

${ }^{30}$ See Feigenbaum in Emiliani 1993, 120.

${ }^{31}$ On Ludovico's reception of the Discorso intorno alle immagini sacre e profane (1582) by Paleotti and the debate on the iconography of the Assumption of the Virgin see Pinnel 1958; Prodi 1959-1967, 2 vol., 545-549; Prodi 1962 [2014], 133-138; Street 1970; Feigenbaum 1984, 143-162; 360-361 (n. 101); Feigenbaum in Emiliani 1993, 120-122; Prodi 2012, 26-3; Pierguidi 2018, 129-131.

${ }^{32}$ Feigenbaum 1984, 155.
} 
effort appears in the depiction of this subject. ${ }^{33}$ There is an apostle in the left foreground who, planting his feet in the ground, pushes the tomb up with both hands, helped by three other figures. This solution was also adopted in the fresco of the Raising of Lazarus painted by Giotto in the Scrovegni Chapel in Padua and by the Limbourg brothers in a miniature of the Très riche heures $d u$ Duc du Berry depicting the same subject. ${ }^{34}$ However, in these earlier examples the physical effort is manifest only in the leaning pose of the figure rather than to his muscular tension. Feigenbaum suggested that Ludovico may have used the angel painted by Tintoretto in the Resurrection of Christ for the Scuola Grande di San Rocco as a model. ${ }^{35}$ This is especially fascinating if one also analyses the preparatory drawing by Robusti, now in the Courtauld Institute, in London. ${ }^{36}$ Here, the pose of the angel from behind, the same pose as that of the apostle in Ludovico's painting, allows the artist to focus completely on rendering the muscles strained by the effort, which is depicted as truthfully as possible.

This also happens in the canvas painted by Ludovico for the Cathedral of Piacenza. The main difference here from the painting for the Corpus Domini is the absence of the mystical event. The only divine details are the angels appearing from the clouds. This may be justified by the final setting of the painting, which, together with the altarpiece of the Death of the Virgin by Camillo Procaccini and the Funeral of the Virgin by Ludovico, decorated the walls of the apsis. All three works depict episodes focused on the end of the earthly life of the Virgin, while the decoration of the ceiling celebrates her Assumption and Coronation among the triumphant angels and the Patriarchs of the Limbo. As the canvas depicting the apostles at the tomb was part of a more complex decoration, it was not necessary to repeat the scene of the Assumption of the Virgin. To enhance the earthly quality in the scene of the discovery of the tomb, Ludovico decided to convey the physical effort again through the depiction of a figure seen from behind: in the right foreground, an apostle shows his tense back as he puts down the heavy slab used to cover the tomb. The emphasised linearity of his muscles is probably due to the large dimensions of the painting $(665 \times 343 \mathrm{~cm})$ and the distance from which it was meant to be observed. This appears to contradict Ludovico's pursuit of rendering the anatomy of the body as naturally as possible, and it can be explained with his desire to enhance the link between pose and action.

Beginning with the depiction of Hercules in the eighth scene in Palazzo Fava, which illustrates The Argonauts in the Lybian Desert, all the examples analysed interpret the pose-action pair as an expression of strenuous effort. ${ }^{37}$ Nevertheless, as already mentioned, in the same

\footnotetext{
${ }^{33}$ Staedel 1935, 183.

${ }^{34}$ See Grazioli 2014, 74.

${ }^{35}$ Emiliani 1993, 122 (n. 7).

${ }^{36}$ For Tintoretto's drawing see Echols and Ilchman 2018, 186; 263 (no. 171). As Tintoretto completed the Resurrection in 1581, and Ludovico stayed in Venice before 1580, he could not have seen the work directly (see Stanzani in Emiliani 1993, 202-203). However, Agostino went to Venice at least twice before Ludovico completed his painting in 1601 (1582; 1587-89) (see Benati 1986, 255) and Annibale made a trip to Venice at the beginning of the 1580s (Dempsey 1986, 239). ${ }^{37}$ Another example is the Rückenfigur depicted by Annibale in the foreground of the episode representing Romulus tracks with the plow the boundaries of Rome in Palazzo Magnani (Bologna). On this scene see Vitali 2011, 140-143. The author suggests finding a prototype for the naked Rückenfigur, in the canvas representing the Last Judgement, realised by Tintoretto for the Church of Madonna dell'Orto (Venice). In particular, Vitali refers to the Saint seen from behind represented below Christ (Vitali 2011, 142). Previously, Emiliani had already suggested a possible prototype, that is the Apostle seen from behind depicted by Girolamo Siciolante da Sermoneta in the Assumption of the Virgin (Rome, Santa Maria
} 
context there is a fresco where the hero is seen from behind but at rest, simply observing the scene. ${ }^{38}$ The success of the Rückenfigur during the modern era, from the revolutionary example by Giotto to its triumph in Friedrich and in Hammershøi's paintings, is closely connected to the need to focus the gaze of the beholder. ${ }^{39}$ One of the clearest and most famous cases of this function given to the figure from behind is the Madonna of the Chancellor Rolin by Jan van Eyck. Behind the main scene of the patron and the Virgin, two small figures turn their back to the viewer and to the foreground in order to admire the open landscape in front of them. Millard Meiss dubbed them "the first figures in the history of painting who are entirely preoccupied with a view". ${ }^{40}$ If they are not the first figures used as spectators in a painting, this is the first time that their gaze is not directed towards the main scene, a device that became very successful. ${ }^{41}$ For instance, some paintings of the Bolognese school present the same device. In particular, the Saint Jerome by Lorenzo Sabatini, ${ }^{42}$ the Portrait of a Woman in the Palazzo Davia Bargellini by Prospero Fontana ${ }^{43}$ and the Astronomer in the Galleria Spada -attributed to Prospero Fontana or to Bartolomeo Passerotti. ${ }^{44}$ The main difference between these works and the Flemish painting is the Rückenfiguren's viewpoint: in Van Eyck's painting, as the figures are on the perspective axis, they appear both as symbols of our ability to see and as a guide to the viewer's gaze, making it essential for the viewer to share the object of their observation. ${ }^{45}$ In the Bolognese paintings this act of sharing does not happen. The object of observation of the figures looking out the window is not part of our visual field, thus making it difficult to justify their presence in the paintings.

The irrelevance of the figure from behind to the foreground scene and our inability to know what they are looking at are also elements of the enigmatic engraving by Agostino Carracci Ogni cosa vince l'oro (FIG. 7). In the background, looking out from a terrace is a Rückenfigur who does not share any narrative links with the scene taking place behind her: an elderly man with his hands "al carniero" - quoting Malvasia - is about to benefit from the service offered by the naked young girl, sanctioning the end of Love (as shown by Cupid breaking the arch). ${ }^{46}$ The room where the sexual intercourse will occur opens onto a terrace to the left, where a child is playing and the Rückenfigur may be looking at what is perhaps Saint Mark's Square in Venice. ${ }^{47}$

dell'Anima, Fugger Chapel; see Emiliani 1984, 100). However, in this figure the attention reserved to the representation of the back's muscles is lost; indeed, it is covered by a long drapery.

${ }^{38}$ It is the episode depicting The Embarkation of the Argonauts (see n. 7).

${ }^{39}$ See Koch 1965; Koerner 2009; Banu 2000; Wilks 2005; Prange 2010; Grazioli 2014; Imbert 2015; Rubin 2018. On Hammershøi's use of the Rückenfigur see Esposito 2019; Esposito (in press).

${ }^{40}$ Meiss 1976, 51.

${ }^{41}$ See Imbert 2015.

42 Benati 2019.

${ }^{43}$ Ghirardi 1994, 148-150.

${ }^{44}$ Ghirardi 1994, 148-150 (as Fontana); for the attribution to Bartomoleo Passerotti see Zeri 1954, 103-104. A preparatory drawing for the Astronomer has been attributed to Vasari by Florian Härb (Härb 2015, 567-568, no. 379). The motif of the Rückenfiguren at the window appears in some other drawings which date from the $1540 \mathrm{~s}$, the authorship of which is still debated between Vasari and Fontana (see Härb 2015, 244-246, no.101-102).

${ }^{45}$ Imbert 2015, 38.

${ }^{46}$ Malvasia 1678, I, 98. See also Simons 2009, 209.

${ }^{47}$ This hypothesis is based on the recognisable shape of Saint Mark's Campanile; this setting could be further proof that this engraving was made when Agostino was in Venice, at the begin of 1582 or between 1587 and 1589 . For the debate 
According to Patricia Simons, the figure from behind might be the governess of the child - the son of the courtesan - who, distracted by what she is looking at, will not be able to spare the child a nasty fall if he continues to lean over to grab the apple. ${ }^{48}$ Marzia Faietti also reflected on this figure, merely asserting that in her opinion this is a male character. ${ }^{49}$ After interpreting the engraving as a representation of the three ages of man in different approaches towards lust, Faietti considers the explanation provided by Lionel Dax in his monography on The Lascivious series. ${ }^{50}$ Dax suggested that this engraving is to be read in a biographical way: Agostino, who according to Malvasia had a relationship with the courtesan Isabella in Venice, portrays himself on the terrace turning his back from her, while she is busy fulfilling her work duties. ${ }^{51}$ The child would be Antonio, the son Agostino had from Isabella and who he would then bring with him to Bologna.

It has long been debated whether this engraving belongs to The Lascivious series: ${ }^{.52}$ against its inclusion are its dimensions, which are slightly larger than the other prints of the series, and some narrative or pictorial details, which are not present in the other engravings. ${ }^{53}$ These details enrich the setting with familiar aspects that are missing from The Lascivious, where the characters are Biblical or mythological. Therefore, we can surmise that the figure from behind looking out from the terrace is one of the details that do not formally interact with the erotic scene in the foreground but contribute to bring it closer to reality. An ancillary figure, whose apparent futility introduces an element of chance in the composition prefiguring an ante litteram snapshot. This composition is a perfect example of the "poetica dell'immediato e del quotidiano" - the poetics of the immediate and the ordinary - recognised by Andrea Emiliani in Carracci's art. ${ }^{54}$ Our interpretation of the figure from behind can be further substantiated by a comparison with the above-mentioned painting by Lorenzo Sabatini. Here, the two figures in the background have no other function but to make the present burst into the composition, to emphasise that Saint Jerome is meditating on the Cross inside a rich Bolognese interior of the second half of the $16^{\text {th }}$ century.

Thanks to the attention to the 'vero' shared by the three cousins, our research on the Rückenfigur can be further developed in another direction, which will take us to a totally different conclusion: the complete absence of any relationship between pose and action. The series of etchings by Simon Guillain after drawings by Annibale known as Diverse Figure (Rome, 1646) is a perfect case in point here. ${ }^{55}$ Fourteen of the eighty etchings of this series, which depict the various labours or crafts in Bologna, show the worker from behind

on the date of the engraving see Bodmer 1940, 48; DeGrazia 1984, 176 (no. 190); Sutherland Harris 2000; Bury 2001, 196-198; Faietti 2007; Faietti 2009, 79; Simons 2009, 206; Pasquali 2018.

${ }^{48}$ Simons 2009, 206-207.

${ }^{49}$ Faietti 2009, 80.

${ }^{50}$ Dax and de Butler 2003, 42-26.

${ }^{51}$ Malvasia 1678, 518.

${ }^{52}$ See Faietti 2007; Faietti 2009; Simons 2009. The same problem also applies to the engraving The Satyr Mason.

${ }^{53}$ Faietti 2007, 159; Simons 2009, 198.

${ }^{54}$ Emiliani 1993, XXVI.

55 See McTighe 1993; Robertson 1997, 20-23; Benati and Riccomini 2006, 28-29; Robertson 2008, 36; Sapori 2011; Sapori 2015. 
(FIGS. 7-8). ${ }^{56}$ Here it is difficult to give the pose a purpose specifically connected to the depiction of these particular trades: the fourteen workers could have been shown facing the viewer or in profile without adding or detracting from our understanding of their job. To further demonstrate how this pose is a completely arbitrary element, one can compare this series with the approximately contemporary Ritratto de Quelli che Vano Vendendo et Lavorando per Roma (1582) by Ambrogio Brambilla. In this series, some of the same workers that Carracci depicted from behind are portrayed in profile or three-quarter. The choice of depicting the figures from behind is functional to the appreciation of details - which otherwise would have not been visible - in other kind of series, such as those by Enea Vico (Diversarum Gentium Nostrae Aetatis Habitus, 1558), Ferdinando Bertelli (Omnium fere gentium nostrae aetatis habitus, 1563) and Cesare Vecellio (Degli Habiti antichi e moderni, 1590). ${ }^{57}$ As Giovanna Sapori observed, in the Diverse Figure there are also some figures that could be included in a specific figurative tradition, such as the Facchino (FIG. 8).$^{58}$

By contextualising Annibale's series in a broader figurative tradition which, from the French Cris de la ville, contributed to the emergence of the depiction of the Labours as a specific genre, other interesting elements emerge to analyse this pose. ${ }^{59}$ As well as identifying possible models - such as the above-mentioned series by Brambilla and that by Lorenzo Vaccario (Arti di Roma, 1585) ${ }^{60}$ - the comparison between Annibale's series and earlier ones clearly highlights the novelties of the Diverse figure: as noted by Giovanna Sapori, the most innovative element of the Diverse figure is the use of very concise solutions for the narrative and for the contextual effects. In addition to the precision in the description of the goods, tools, animals, wagons, there is the simplicity of the gestures of the sellers, of the movements of the workers, which recall studies from life. The frequent use of diagonal lines, the narrative of the dialogue and the portrait of the city are all also equally distinctive features. ${ }^{61}$ It is a new, original work, extraneous to any practical purpose - linked to the representation of the professions of the city - or playful purpose, linked to the mockery of the poorest classes. ${ }^{62}$ However controversial the genesis of this series might be, its individual inventions attest above all an interest in reality, in the 'vivo' that transcends any caricatural or grotesque digression and any idealization. ${ }^{63}$ Sheila McTighe also indicates how the problem raised by the Diverse Figure is related to purely artistic matters: how to justify the publication in Rome, the city that saw the Annibale devoted to the Idea, of a volume that shows an absolute tension towards Nature in every single detail? She attempted to answer this with two questions:

\footnotetext{
56 The Facchino (no.2); the Vende paste per i sorci (no. 13); the Chiavaro (no. 26); the Fornaro (no. 27); the Imbiancantore (no. 30); the Vende aceto (no. 33); the Rotatore (no. 42); the Beccamorto (no. 43); the Netta pozzi (no. 45); the Rastrellino per l'uva (no. 48); the Cacciator da lepri (no. 64); the Pescatore (no. 67); the Sediaro (no. 69); the Ciambellaro (no. 72).

${ }^{57}$ See Sapori 2015, 17-29; 79-94.

${ }^{58}$ Sapori 2015, 87-92.

${ }^{59}$ Sapori 2015, 17.

${ }^{60}$ Posner 1971, 17; McTighe 1993, 79-82; Sapori 2015, 79-94.

${ }^{61}$ Sapori 2015, 84-85. To confirm these innovative aspects, it is also possible to refer to drawings and paintings by Annibale depicting workers (see Benati, Riccomini 2006, 28-29; Sapori 2015, 95-131).

62 The introductory text to the prints, signed by Antonio Massani, clarifies the irrelevance of any 'social' purposes for this work (see Mahon 1947, 109-154; McTighe 1993, 76-78; 82-85).

${ }^{63}$ See Sapori 2015, 85. The series was published many years after Annibale's death and there is no evidence that suggests Annibale's desire to publish the drawings as prints in a volume.
} 
"what constitutes the signs for the "natural' here?" and "what make up the signs for the "ideal' form here?". ${ }^{4}$ As part of our research into the figure from behind, it is possible to rephrase the first question as: can the decision to portray a character from behind be considered as a 'sign for the natural'? Portraying a character from behind means making sure that - despite not being able to see the artist's gaze - this figure would move naturally, unaware of being the subject of an image. Furthermore, a man seen from behind makes the fortuity with which the artist's eye approaches reality explicit, not in a pose but rather presenting himself in an anti-pose precisely because of his unawareness and resulting spontaneity. In this interpretation, this viewpoint is a proof of truth: it has no meaning except that of referring to the reality and the contingency of the moment. As Roberto Zapperi pointed out, this does not imply a vision of art as an impromptu and immediate practice; ${ }^{65}$ according to McTighe, it is rather to satisfy that "powerful impetus to find new graphic signs that give the 'effect of the real', to borrow Barthes". ${ }^{66}$ Although McTighe mentioned Barthes's essay solely for its title, $L$ 'effet de réel, this text is an extremely valid theoretical reference regarding the consideration that we are proposing here. Aimed at investigating the aspects of the narrative that are apparently meaningless but without which the 'real'- to be understood in its most tangible sense could not invade the work, Barthes's essay poses similar, if not superimposable, questions to ours. Considering the reference to the 'real' an essential element in the historical narrative, Barthes highlights how such a reference can only occur through "superfluous", "useless", "non-functional" elements. ${ }^{67}$ These details, which Barthes defines as "concrete", seem to appeal directly to the beholder by stating: "we are the real". ${ }^{68}$ Although it can be objected that the pose from behind is not formally a sign - as is for instance the barometer mentioned by Barthes from Un coeur simple by Flaubert - it is however one of those "insignificant gestures" and "transitory attitudes" which ensure "the pure and simple 'representation' of the 'real"'. 69

Therefore, the pose of the workers from behind designed by Annibale plays no role in identifying the subject, but precisely through this total absence of meaning it manages to send the viewer back to reality. Quoting Barthes: "the very absence of the signified, to the advantage of the referent alone, becomes the very signifier of realism: the reality effect is produced". 70

This consideration prompts more attention if applied to the drawing attributed to Annibale in the British Museum in London (FIG. 10). ${ }^{71}$ A young boy, seen from behind, is depicted by the artist while he is performing his same action: painting. He is probably a student of the Accademia degli Incamminati. The long tunic leaves only his calves and ankles uncovered. The head slightly tilted downwards and the curved pose suggest the focus of the young man who is about to paint on the canvas with a brush. If it were not for the fragments of the palette and the brush that appear to the left and right of his body respectively, nothing would tell us

\footnotetext{
${ }^{64}$ McTighe 1993, 83.

${ }^{65}$ Zapperi 1989, 62.

${ }^{66}$ McTighe 1993, 83.

${ }^{67}$ Barthes 1989, 146.

${ }^{68}$ Barthes 1989, 148.

${ }^{69}$ Barthes 1989, 146.

${ }^{70}$ Barthes 1989, 148.

${ }^{71}$ Robertson and Whistler 1996, no. 55.
} 
that he is a young painter. Everything remains unspoken: his identity, his physiognomic features, his age. The work being carried out, that is the action of painting, is captured in the most authentic way: from behind.

Annibale's drawing is a perfect conclusion for this research through which we wanted to analyse the figure seen from behind as an agent of meaning or, more precisely, as an agent of 'truth'. As seen from the many examples, the Rückenfigur can be declined in different ways that all have the same purpose, however: to reduce the boundary between art and the real world. In the frescoes of Palazzo Fava and San Michele in Bosco, as well as in the canvases by Ludovico, the view from behind makes it possible to represent the effort more truly. In Agostino's engraving, the little observer in the background not only shares the same position of the beholder in front of the work, but also introduces a sort of randomness into the composition that makes it appear like a snapshot. Finally, the pose from behind of the workers drawn by Annibale refers to the reality of the moment in which the artist placed himself in front of them- or rather, behind them - to portray them. Despite subtle differences, these case studies indicate the same direction in which the Carracci conducted their artistic research, whose goal has always been the true, or quoting Annibale, the 'vivo'.

\section{Luca Esposito}

Sapienza - University of Rome

luca.esposito@uniromal.it 


\section{BIBLIOGRAPHY}

Ambrosini Massari A.M. 2009: "Appunti su Barocci e Bologna, dai Carracci a Crespi", in Federico Barocci 1535-1612. L'incanto del colore. Una lezione per due secoli (catalogo della mostra), Milano, 124-137.

Banu G. 2000: L’homme de dos: peinture, théâtre, Paris.

Barone J. 2015: “'et de' suoi amici’: the early Transmission of Leonardo's "Treatise on Painting"' in: Leonardo da Vinci 1452 - 1519. The Design of the World, Milano.

Barthes R. 1989: "The Reality Effect", in The Rustle of Language, Berkeley, 141-148.

Bellori G.P. 1672: Le vite de' pittori scultori et architetti moderni, Roma.

Benati D. 1986: "Agostino Carracci", in Nell'età di Correggio e dei Carracci. Pittura in Emilia dei secoli XVI e XVII (catalogo della mostra), Bologna, 255256.

Benati D. 2016: "Sull'idea del 'vero' in Annibale Carracci", in ArtItalies 22, 6-15.

Benati D. and Riccomini E. 2006: Annibale Carracci (Exhibition catalogue: Bologna, Museo Civico Archeologico 22/09/2006-07/01/2007; Roma, Centro Culturale Internazionale Chiostro del Bramante, 25/01-06/05/2007), Milano.

Benati D. 2019: "Lorenzo Sabatini, Saint Jerome in Prayer", in Fondantico. Tefaf Maastricht 2019, Bologna, 11-13.

Bodmer H. 1940: "Die Entwicklung der Stechkunst des Agostino Carracci”, in Die Graphischen Kunste, Wien, 41-71.

Brogi A. 2001: Ludovico Carracci (1555 - 1619), Ozzano Emilia.

Bury M. 2001: The Print in Italy. 1550-1620 (Exhibition Catalogue), London.

Campanini M.S. 1994: Il chiostro dei Carracci a San Michele in Bosco, Bologna.

Campbell S. 2002: "The Carracci Visual Narrative and Heroic Poetry after Ariosto: The "Story of Jason" in Palazzo Fava", in Word and Image 18, 210-230.

Ciardi R.P. 1993: “'Intus et extra': lo studio dell'anatomia nell'Accademia dei Carracci", in Atti e memorie Accademia Clementina 32, 209-222.

Dax L., de Butler A. 2003: Augustin Carrache. Les Lascives, Paris.

DeGrazia D. 1984: Le stampe dei Carracci con i disegni, le incisioni, le copie e i dipinti connessi; catalogo critico, Bologna.
Dempsey C. 1986: "La riforma pittorica dei Carracci", in Nell'età di Correggio e dei Carracci. Pittura in Emilia dei secoli XVI e XVII (catalogo della mostra), Bologna, 237-254.

Dempsey C. 2013: "Malvasia's Il Claustro di S. Michele in Bosco (Bologna, 1694)", in G.M. Anselmi, A. De Benedictis, N. Terpstra (a cura di), Bologna Cultural Crossroads from the Medieval to the Baroque (Atti del convegno: Bologna 20-21/06/2011), Bologna, 107-112.

Dufresnoy C.-A. 2005 [1668]: De Arte Graphica, edition, translation and commentary by C. Allen, Y. Haskell, F. Muecke, Geneva 2005.

Echols R., Ilchman F. 2018: Tintoretto. Artist of Renaissance Venice (catalogo della mostra), Venezia.

Emiliani A. 1984: Bologna 1584. Gli esordi dei Carracci e gli affreschi di Palazzo Fava, Bologna.

Emiliani A. 1993: Ludovico Carracci (catalogo della mostra), Bologna.

Esposito L. 2019: “Quand le silence donne voix à l'art: Vilhelm Hammershøi et Maurice Maeterlinck", in C. Armand (dir.), Voix et silence dans les arts. Passages, poïesis et performativité (Conférence internationale: Nancy, 14-17/06/2017), Nancy, 145-154.

Esposito L. (in press): "Dipingere il silenzio: Vilhelm Hammershøi e i luoghi dell'inespresso" in Il silenzio delle immagini. Teorie e processi dell'invenzione artistica (Conferenza internazionale: Roma, MAXXI, 11-12/12/2015).

Faietti M. 2007: "Rebus d'artista Agostino Carracci e 'La carta dell'ogni cosa vince 1'oro'", in Artibus et Historiae 28, 155-171.

Faietti M. 2009: "Carte lascivie e disoneste di Agostino Carracci”, in M. Koshikawa (a cura di), L'arte erotica del Rinascimento (Conferenza internazionale: Tokyo, National Museum of Western Art, 29/03/2008), Tokyo, 81-99.

Feigenbaum G. 1984: Lodovico Carracci. A study of his later career and a catalogue of his paintings, Ann Arbor.

Ghirardi A. 1994: "Ritratto e scena di genere. Arte, scienza, collezionismo nell'autunno del Rinascimento", in V. Fortunati, La pittura in Emilia e in Romagna. Il Cinquecento: un'avventura artistica tra natura e idea, Bologna, 148-183.

Grazioli L. 2014: Figura di schiena, Milano. 
Härb F. 2015: The Drawings of Giorgio Vasari (15111574), Roma.

Holt E.B.G. 1958: A Documentary History of Art, 3 voll., Garden City 1957-1966, II, Michelangelo and the Mannerists, the Baroque and the Eighteenth Century, 1958.

Imbert A.-L. 2015: "Regardeurs, flâneurs, voyageurs dans l'horizon d'une culture prémoderne du paysage. Quelques réflexions à partir du Bon gouvernement d'Ambrogio Lorenzetti", in A.-L. Imbert (dir.), Regardeurs flâneurs voyageurs dans la peinture (Conférence internationale: Paris, CHAR, 56/06/2009), Paris, 31-52.

Keazor H. 2007: "Il vero modo": die Malereireform der Carracci, Berlin.

Koch M. 1965: Die Rückenfigur im bild Von der Antike bis zu Giotto, Bonger.

Koerner J.L. 2009: Caspar David Friedrich and the Subject of Landscape, London.

Laurenza D. 2005: "Possibili tracce di Leonardo nella cultura artistico-scientifica bolognese all'epoca di Passerotti e dei Carracci (una incisione di soggetto animalistico il Codice Huygens)", in Raccolta Vinciana 31, 331-351.

Leonardo, da Vinci 1721: A Treatise of Painting, London.

Leonardo, da Vinci 1995: Libro di pittura, Firenze.

Mahon D. 1947: Studies in Seicento Art and Theory, London.

Malvasia C.C. 1678: Felsina pittrice. Vite de' pittori bolognesi, 2 voll. I-II, Bologna.

Malvasia C.C. 1686: Le pitture di Bologna, Bologna.

Malvasia C.C. 1694: Il claustro di San Michele in Bosco, Bologna.

McTighe S. 1993: "Perfect Deformity Ideal Beauty and the 'Imaginaire' of Work: the Perception of Annibale Carracci's 'Arti di Bologna' in 1646", in Oxford Art Journal 16 (1), 75-91.

Meiss M. 1976: The Painter's Choice. Probelms in the Interpretation of Renaissance Art, New York.

Pasquali T. 2018: "Agostino Carracci, nos.169-177", in L'eterno e il tempo, tra Michelangelo e Caravaggio (catalogo della mostra), Milano, 424-425.

Pedretti C. 1996: "The Dart Caster", in Achademia Leonardi Vinci: the Armand Hammer Center for Leonardo Studies at UCLA, 9, 55-72.

Perini Folesani G. 1981: "Il lessico tecnico del Malvasia”, in Convegno nazionale sui lessici tecnici del Sei e Settecento, (Conferenza: Pisa, Scuola Normale Superiore, 1-3/12/1980), 1 vol., Pisa, 219-153.

Perini Folesani G. 1990: Gli scritti dei Carracci: Ludovico Annibale Agostino Antonio Giovanni Antonio, Bologna.
Perini Folesani G. 2006: "Il fregio con le storie di Giasone dipinto dai Carracci a Palazzo Fava Bologna”, in Mediterranean Myths from Classical Antiquity to the Eighteenth Century, Ljubljana, 189. 211.

Pierguidi S. 2014: "Le aporie della critica di Malvasia: tra difesa del primato lombardo e ossequio alla teoria eclettica", in ArtItalies 20, 68-78.

Pierguidi S. 2018: "Fedeltà alle fonti e rispetto della tradizione nell'età della Controriforma: gli apostoli presenti all'AAssunzione di Maria' al tempo dei Carracci", in I. Foletti, M. Gianandrea, S. Romano, E. Scirocco (eds.), Re-thinking re-making re-living christian origins, Roma, 121-146.

Pigozzi M. 2012: "Bologna: dall'anatomia agli esemplari del corpo", in Anatome: sezione scomposizione raffigurazione del corpo fra Medioevo e età moderna, Bologna, 87-116.

Pigozzi M. 2013: “Annibale Carracci. 'Al vivo rappresentava non pur le parti del corpo, ma quelle dell'animo'", in V. Stoichita, M. Portmann, D-A. Boariu (dir.), Le corps transparent (Conférence internationale: Roma, Istituto Svizzero, 11-12/06/2010), Roma, 195-214.

Pinnell M. 1958: "Lodovico Carracci's Assumption of the Virgin", in North Carolina Museum of Art bulletin 1, 1-7.

Posner D. 1971: Annibale Carracci. A Study in the Reform of Italian Painting around 1590, New York.

Prange R. 2010: "Sinnoffenheit und Sinnverneinung als metapicturale Prinzipien zur Historizität bildlicher Selbstreferenz am Beispiel der Rückenfigur", in V. Krieger, R. Mader (Hrsg.), Ambiguität in der Kunst: Typen und Funktionen eines anhaltend aktuellen Topos (Internationale Konferenz: Wien, Universität für angewandte Kunst, 05-07/03/2009), Köln, 125-167.

Prodi P. 1959-1967: Il cardinale Gabriele Paleotti (1522-1597), 2 vols., Rome.

Prodi P. 1962: 'Ricerche sulla teorica delle arti figurative nella Riforma Cattolica', in Archivio italiano per la storia della pietà, IV (1965), 121-212, ristampato in $\mathrm{P}$. Prodi, Arte e pietà nella Chiesa tridentina, Bologna 2014, 53-189.

Prodi P. 2012: 'Introduction', in G. Paleotti, Discourse on Sacred and Profane Images, trans. by $\mathrm{W}$. McCuaig, Los Angeles, 1-42.

Robertson C. 1993: "I Carracci e l'invenzione: osservazioni sull'origine dei cicli affrescati di Palazzo Fava", in Accademia Clementina: Atti e Memorie 23, 271-305.

Robertson C. 1997: “Annibale Carracci and 'Invenzione': Medium and Function in the Early Drawings", in Master Drawings 35,1, 3-42. 
Robertson C. 2008: The Invention of Annibale Carracci, Cinisello Balsamo 2008.

Robertson C., Whistler C. 1996: Drawings by the Carracci from British collections (Exhibition Catalogue), Oxford.

Rubin P.L. 2018: Seen from behind. Perspectives on the Male Body and Renaissance Art, New Haven, London.

Sapori G. 2011: "Risfogliando le 'Arti di Bologna': Carracci, Agostini, Massani, Algardi, Guillain”, in S. Ebert-Schifferer, S. Ginzburg, Nuova luce su Annibale Carracci (Conferenza internazionale: Roma, Bibliotheca Hertziana, 26 - 28/03/2007), Roma, 227 253.

Sapori G. 2015: Il libro dei Mestieri di Bologna nell'arte dei Carracci, Roma.

Simons P. 2009: "Agostino Carracci's Wit in two lascivious prints", in Studies in Iconography 30, 198221.

Staedel E. 1935: Ikonographie der Himmelfahrt Mariens, Strassburg.

Street L. 1970: "Lodovico Carracci's Assumption of the Virgin in Modena", in The Art Quarterly 33, 379392.
Summerscale A. 2000: Malvasia's "Life of the Carracci": commentary and translation, University Park.

Sutherland Harris A. 2000: "No. 13: Le Lascivie", in L'idea del bello. Viaggio per Roma nel Seicento con Giovan Pietro Bellori, I-II (catalogo della mostra), Roma, 224-225.

Unger D.M. 2019: Redefining Eclecticism in Early Modern Bolognese Painting. Ideology, Practice, and Criticism, Amsterdam.

Vitali S. 2011: Romulus in Bologna. Die Fresken der Carracci im Palazzo Magnani, München.

Wilks G. 2005: Das Motiv der Rückenfigur und dessen Bedeutungswandlungen in der deutschen und skandinavischen Malerei zwischen 1800 und der Mitte der 1940er Jahre, Marburg.

Zapperi R. 1989: Annibale Carracci. Ritratto di artista da giovane, Torino.

Zeri F. 1954: La Galleria Spada in Roma. Catalogo dei dipinti, Firenze. 


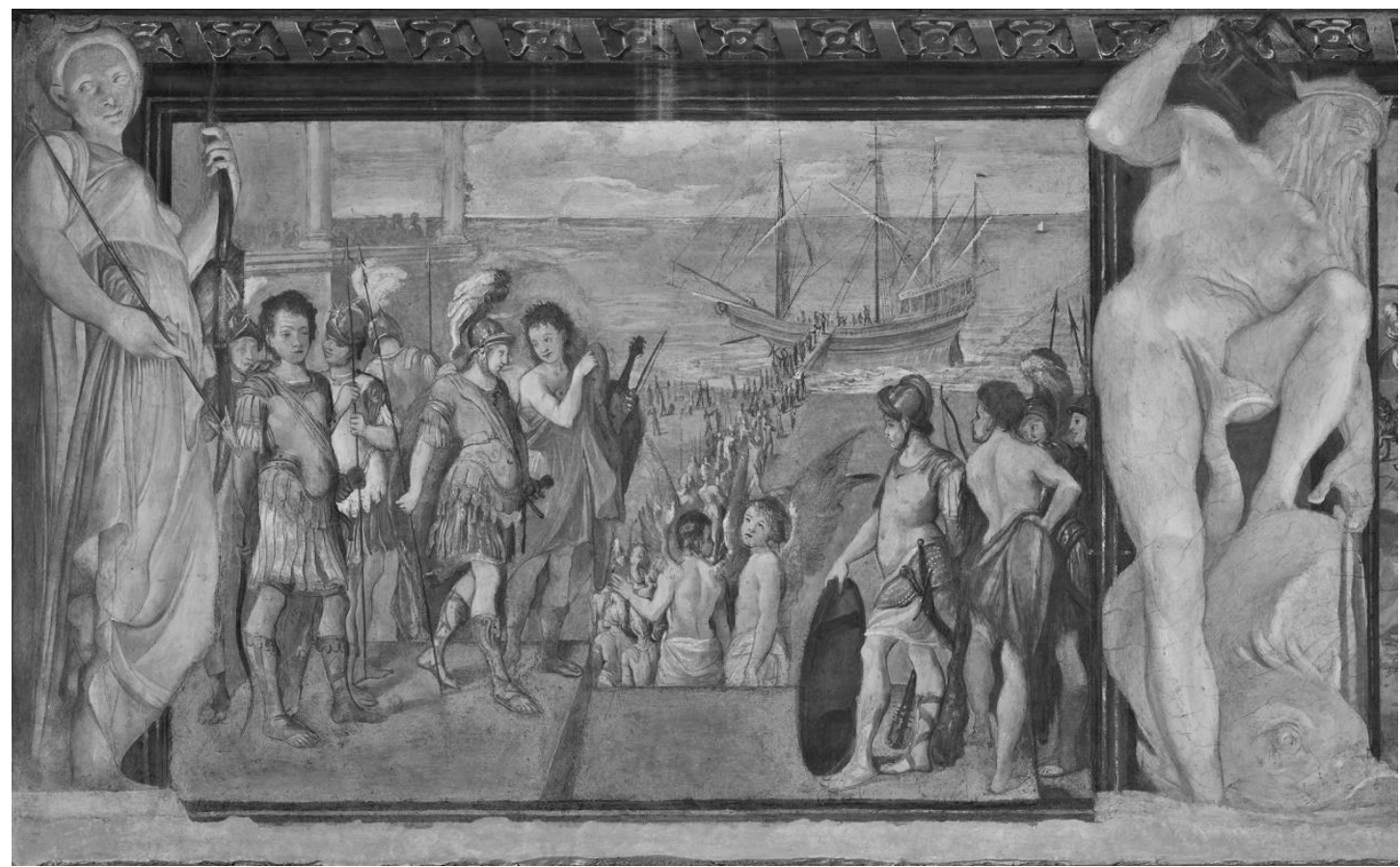

FIG. 1 - Ludovico Carracci, The Embarkation of the Argonauts, 1584, Bologna, Palazzo Fava (copyright Carlo Vannini. Collezioni d'Arte e di storia della Fondazione Cassa di Risparmio in Bologna).

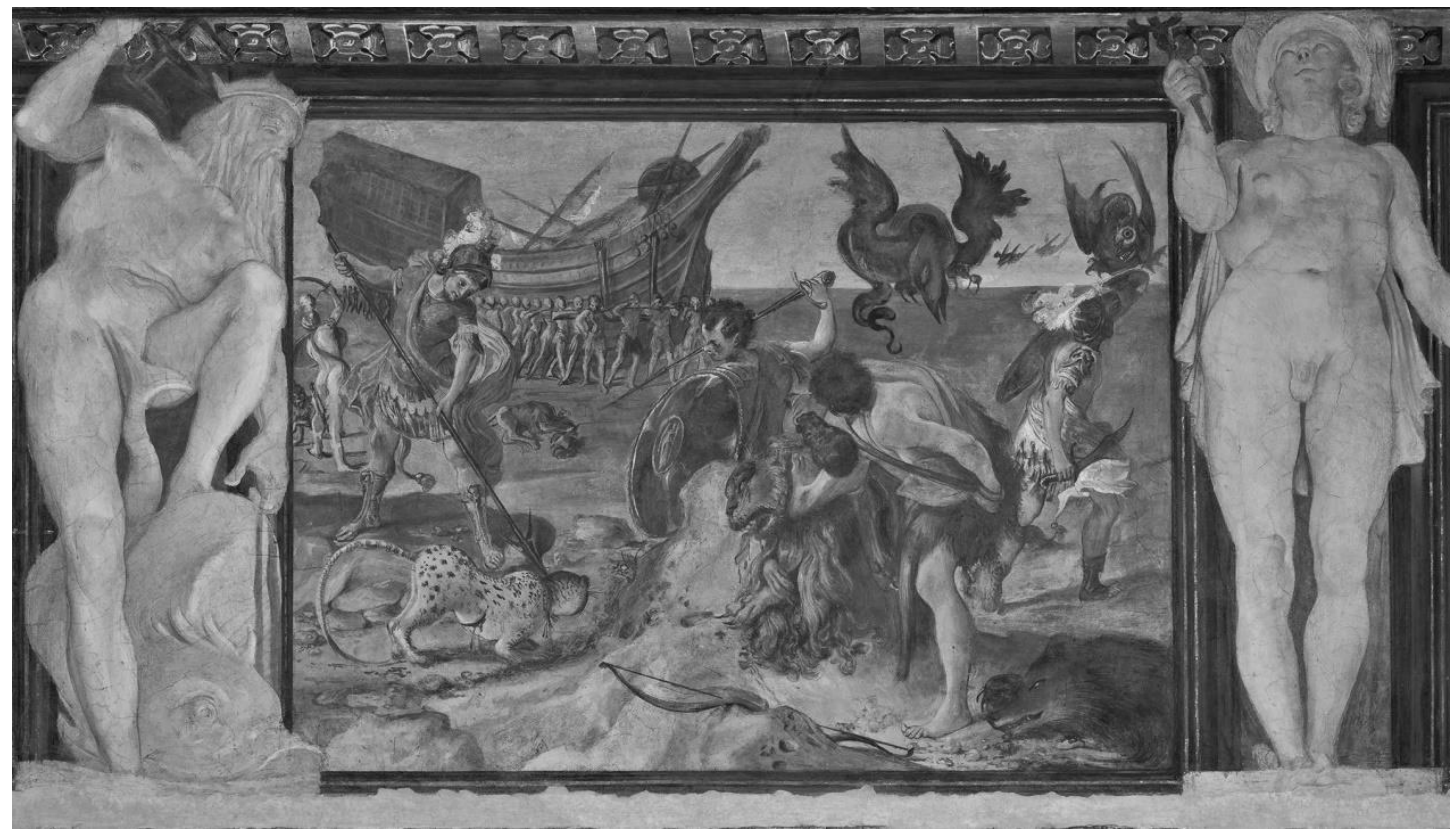

FIG. 2 - Annibale Carracci, The Argonauts in the Lybian Desert, 1584, Bologna, Palazzo Fava (copyright Carlo Vannini. Collezioni d'Arte e di storia della Fondazione Cassa di Risparmio in Bologna). 


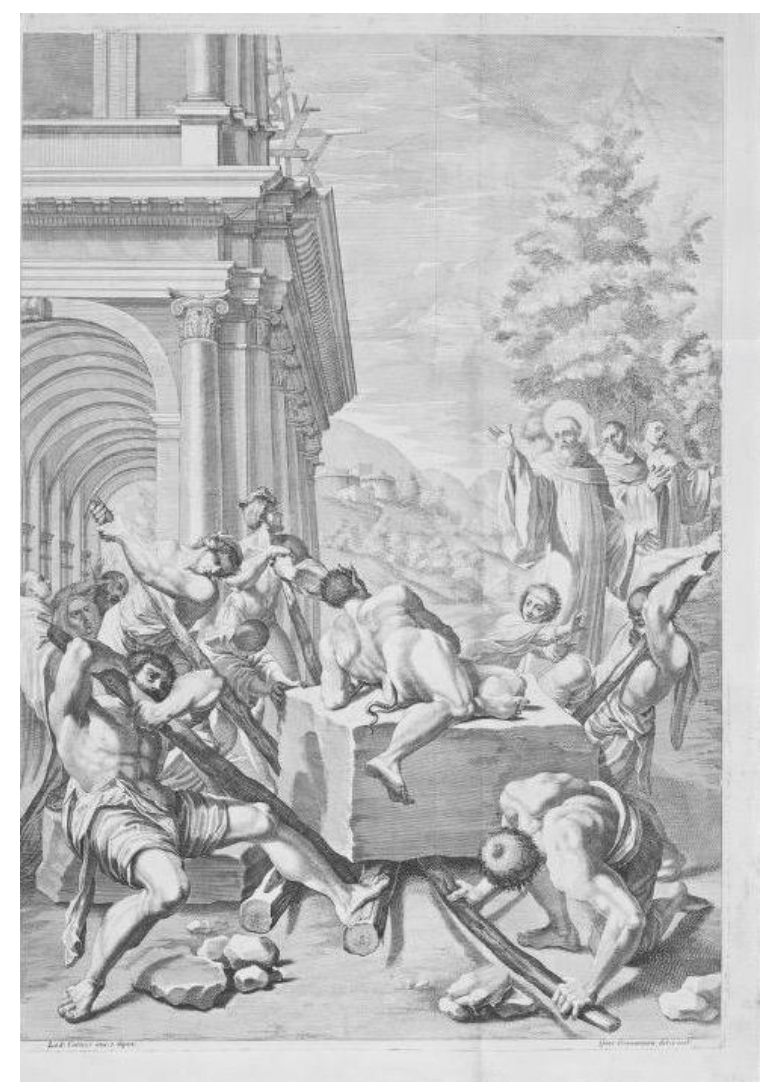

FIG. 3 - Giacomo Maria Giovannini, St. Benedict Drives the Demon off the Immovable Stone, print after the lost fresco by Ludovico Carracci, from Il Claustro di San Michele in Bosco by Carlo Cesare Malvasia, 1694.

FIG. 4 - Giacomo Maria Giovannini, The fire in the Kitchen, print after the lost fresco by Ludovico Carracci, from Il Claustro di San Michele in Bosco by Carlo Cesare Malvasia, 1694.

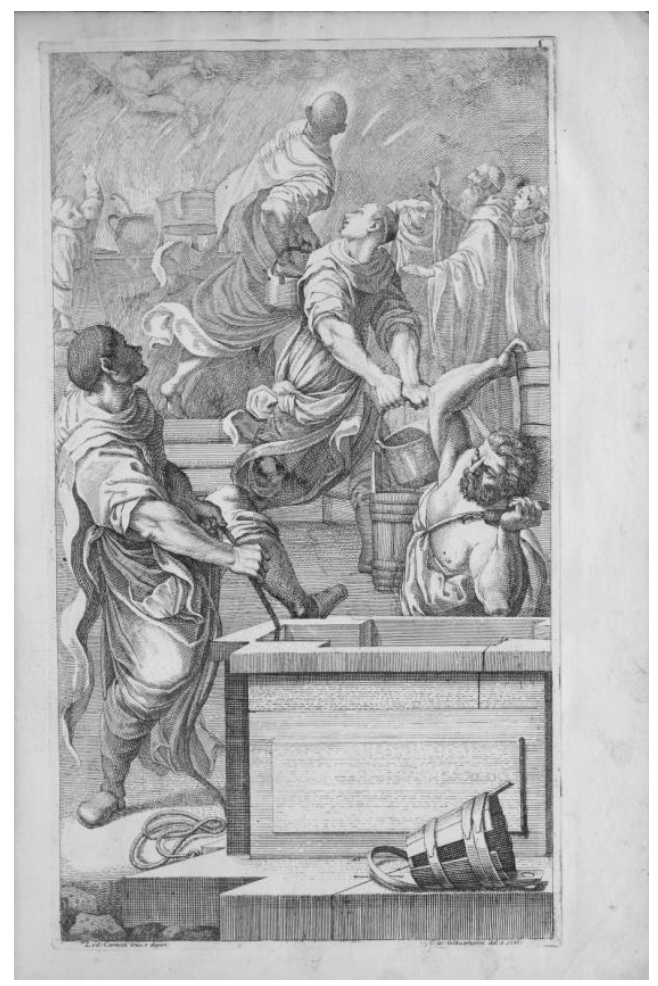




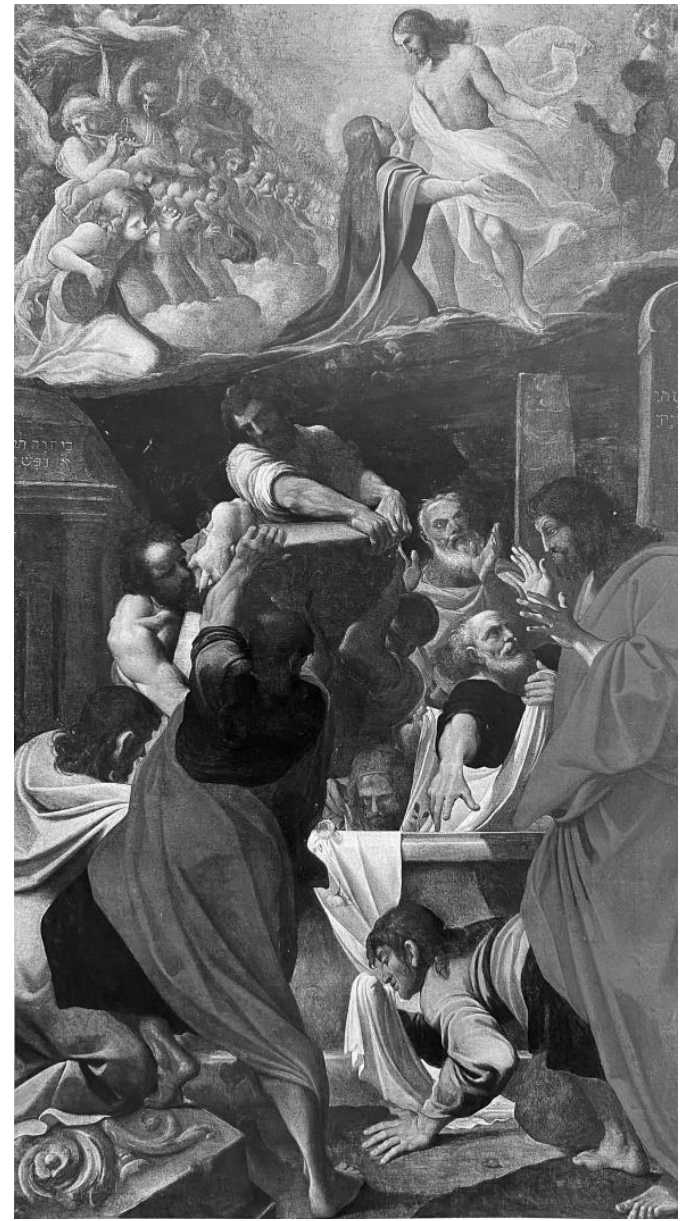

FIG. 5 - Ludovico Carracci, The Apostles at the Virgin's Tomb, 1601, oil on canvas, cm 211 x 145, Bologna, Corpus Domini church (from Emiliani 1993, 121).

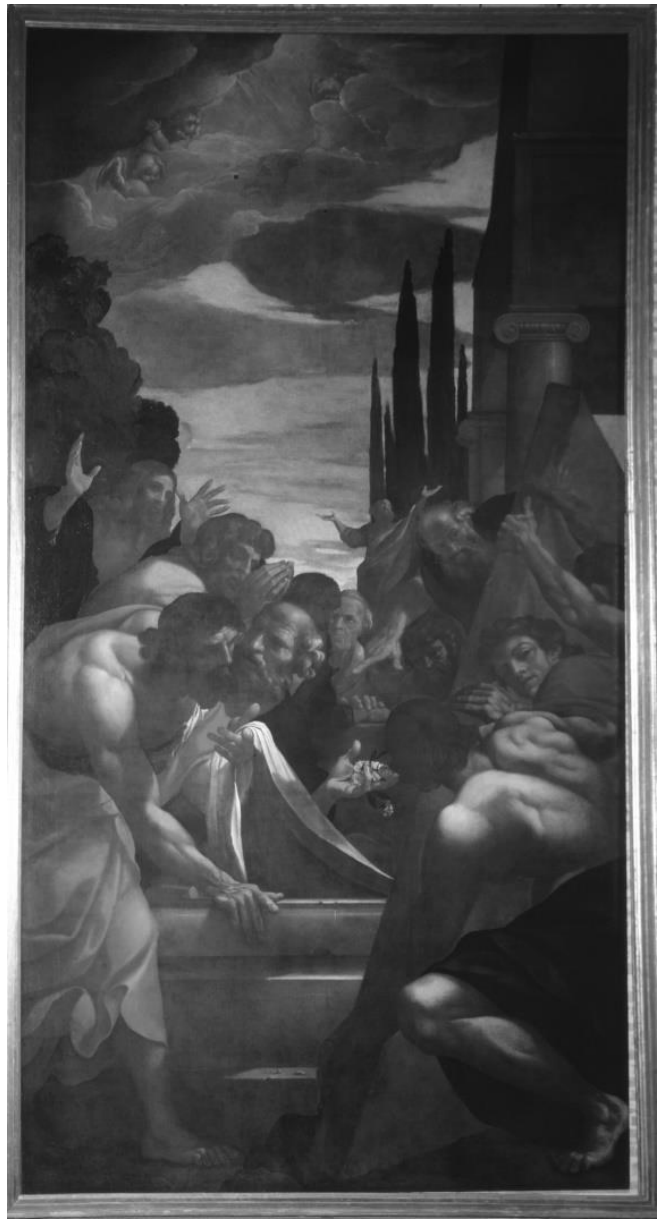

FIG. 6 - Ludovico Carracci, The Apostles at the Virgin's Tomb, 1609, oil on canvas, cm 665 x 346, Parma, Galleria Nazionale (su concessione del Ministero dei Beni e delle Attività culturali - Complesso Monumentale della Pillotta- Galleria Nazionale). 


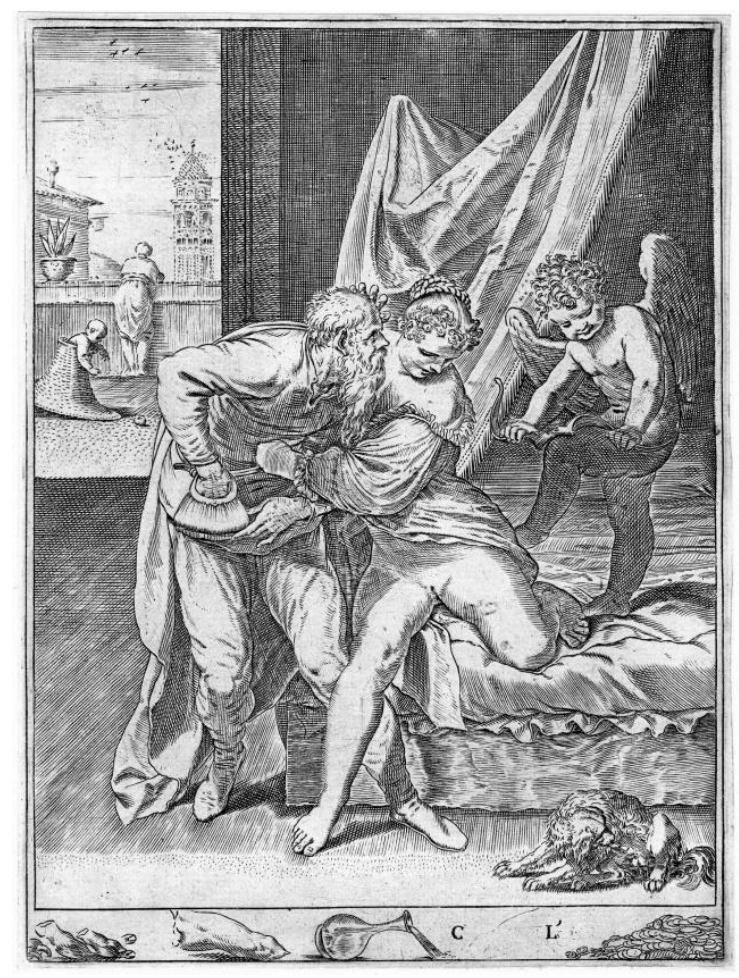

FIg. 7 - Agostino Carracci, Ogni cosa vince l'oro, engraving, mm 214 x 162, London, British Museum (C) The Trustees of the British Museum).

FIG. 8 - Simon Guillain (after Annibale Carracci), Facchino, print, mm $368 \times 245$, 1646, London, British Museum (๑) The Trustees of the British Museum).

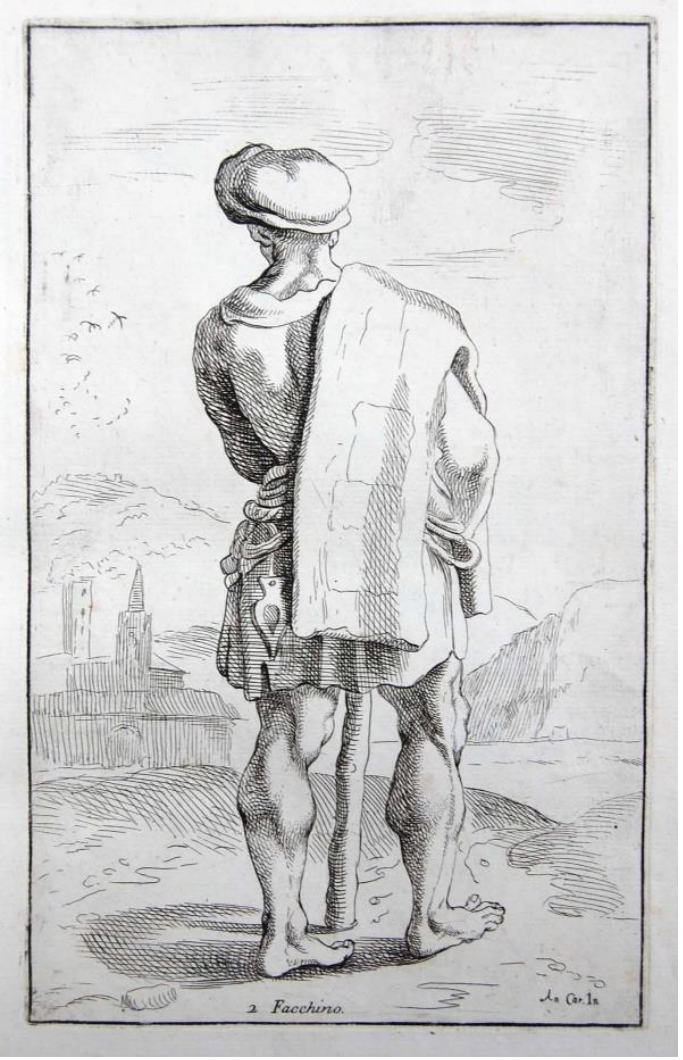


FIG. 9 - Simon Guillain (after Annibale Carracci), Cacciator da lepri, print, mm 368 x 245, 1646, London, British Museum (@) The Trustees of the British Museum).

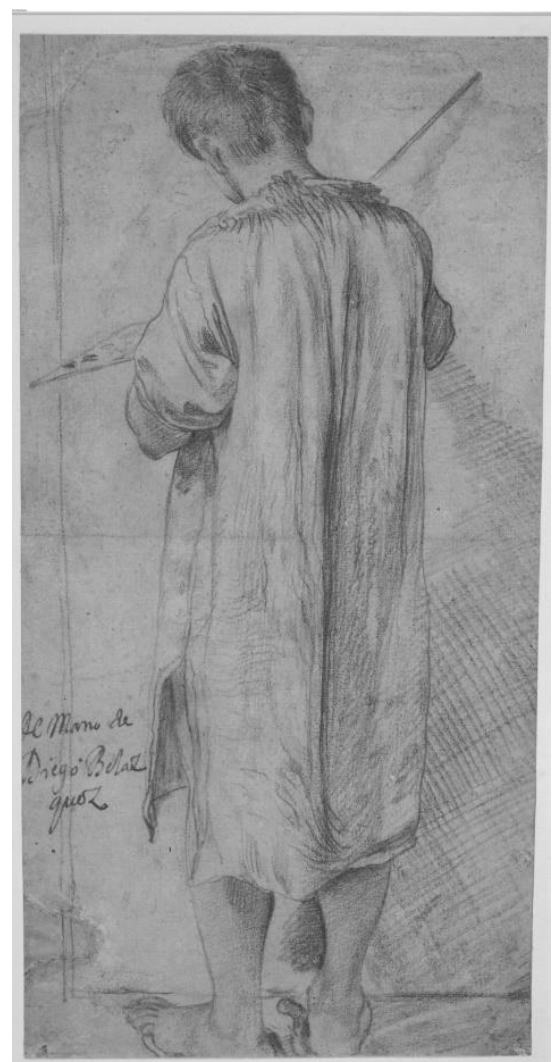

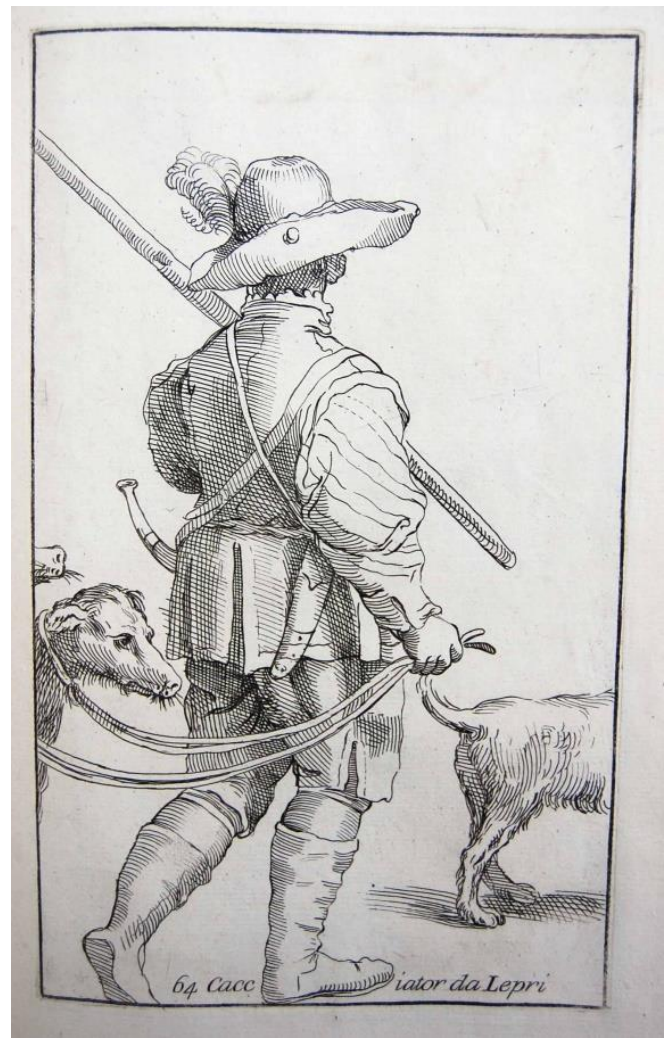

FIG. 10 - Annibale Carracci, A young painter, seen from behind; whole-length standing, holding a palette and brush, wearing a smock, black and red chalk, mm 378 x 178, London, British Museum (@) The Trustees of the British Museum). 
